RHO-BWI-ST-9

\title{
Identification Of Key Radionuclides In A Nuclear Waste Repository In Basalt
}

G. Scott Barney

Bernard J. Wood

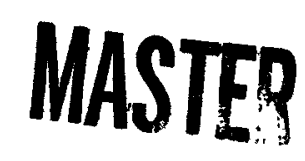

Prepared for the United States

Department of Energy

Under Contract DE-AC06-77RL01030

Rockwell International

Rockwell Hanford Operations

Energy Systems Group

Richland, WA 99352 


\section{DISCLAIMER}

This report was prepared as an account of work sponsored by an agency of the United States Government. Neither the United States Government nor any agency Thereof, nor any of their employees, makes any warranty, express or implied, or assumes any legal liability or responsibility for the accuracy, completeness, or usefulness of any information, apparatus, product, or process disclosed, or represents that its use would not infringe privately owned rights. Reference herein to any specific commercial product, process, or service by trade name, trademark, manufacturer, or otherwise does not necessarily constitute or imply its endorsement, recommendation, or favoring by the United States Government or any agency thereof. The views and opinions of authors expressed herein do not necessarily state or reflect those of the United States Government or any agency thereof. 


\section{DISCLAIMER}

Portions of this document may be illegible in electronic image products. Images are produced from the best available original document. 


\title{
Q.
}

\section{Rockwell International}

\author{
Rockwell Hanford Operations \\ Energy Systems Group \\ Richland, WA 99352
}

\author{
DISClaIMER
}

This report was prepared as an account of work sponsored by an agency of the United States Government. Neither the United States Government nor any agency thereof, nor any of their employees, makes eny werranty, express or implied, or assumes any legal liability or responsibility for the accuracy, completeness, or usefulness of any information, apparatus, product, or process disclosed, or represents that its use would not infringe privately owned rights. Reference herein to any specific commercial product, process, or service by trade name, trademark, manufacturer, or otherwise, does not necessarily constitute or imply its endorsement, recommendation, or favoring by the United States Government or any agency thereof. The views and opinions of authors expressed herein do not necessarily state or reflect those of the United States Government or any agency thereof.

AVAILABLE FROM THE

NATIONAL TECHNICAL INFORMATION SERVICE

SPRINGFIÉLD, VA. 22161

$\begin{array}{ll}\text { PRICE: } & \text { MICROFICHE: } \\ & \$ 3.00 \\ \text { PAPER COPY: } & \$ 4.50\end{array}$ 
IDENTIFICATION OF KEY RADIONUCLIDES

IN A NUCLEAR WASTE REPOSITORY IN BASALT

\author{
G. Scott Barney \\ Material Sciences Group \\ Systems Engineering Department \\ Research and Engineering Function \\ and \\ Bernard J. Wood \\ Engineered Barriers Group \\ Scientific Technologies \\ Basalt Waste Isolation Project
}

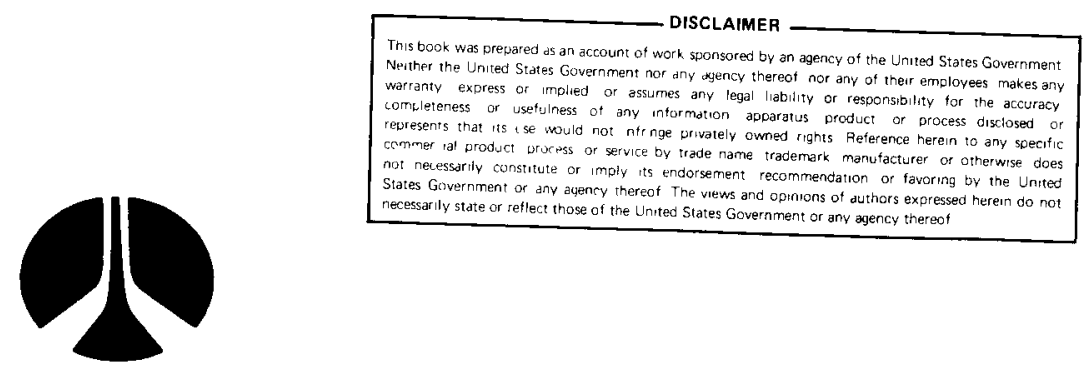

Rockwell International

Rockwell Hanford Operations

Energy Systems Group

Richland, WA 99352 


\section{RHO-BWI-ST-9}

\section{DISTRIBUTION}

This report has been distributed according to the category "Environmental Control Technology and Earth Sciences," UC-11, and "Nuclear Waste Management," UC-70, as given in the Standard Distribution for Unclassified Scientific and Technical Reports, TID-4500. 


\section{RHO-BWI-ST-9}

\section{ABSTRACT}

Radionuclides were identified which appear to pose the greatest potential hazard to man during long-term storage of nuclear waste in a repository mined in the Columbia Plateau basalt formation. The criteria used to select key radionuclides were as follows:

- Quantity of radionuclide in stored waste

- Biological toxicity

- Leach rate of the wastes into groundwater

- Transport rate via groundwater flow.

The waste forms were assumed to be either unreprocessed spent fuel or borosilicate glass containing reprocessed high-level waste. The nuclear waste composition was assumed to be that from a light water reactor.

Radionuclides were ranked according to quantity, toxicity, and release rate from the repository. These rankings were combined to obtain a single list of key radionuclides. The ten most important radionuclides in order of decreasing hazard are: ${ }^{99} \mathrm{Tc},{ }^{129} \mathrm{I},{ }^{237} \mathrm{~Np},{ }^{226} \mathrm{Ra},{ }^{107} \mathrm{Pd}$, ${ }^{230} \mathrm{Th},{ }^{210} \mathrm{~Pb},{ }^{126} \mathrm{Sn},{ }^{79} \mathrm{Se}$, and ${ }^{242} \mathrm{Pu}$. Safety assessment studies and the design of engineered barriers should concentrate on containment of radionuclides in this list. 
TABLE OF CONTENTS

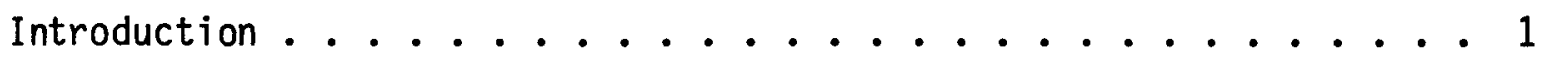

Criteria Used for Selection ............... 1

Quantity of Radionuclide in Waste ............ 2

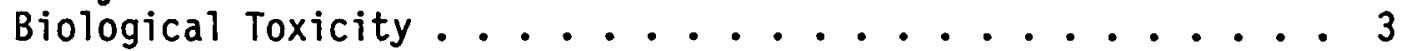

Waste Form Leaching ............... 6

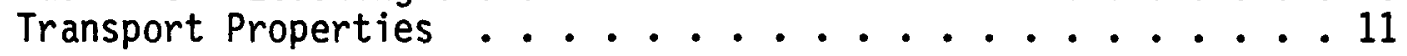

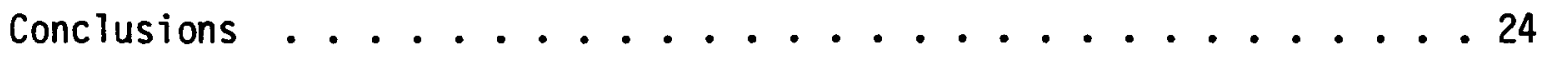

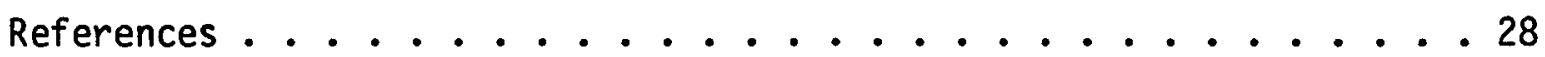

FIGURES:

1 Band Release and Decaying Release Models for Radionuclide Release from a Repository ............. 14

2 Discharge Rates of $79 \mathrm{Se}, 93 \mathrm{Zr}, 129 \mathrm{I}, 135 \mathrm{Cs} \ldots \ldots$

TABLES:

1 Major Radionuclides in Spent Fuel and Solidified HighLevel Waste............... 4

2 Recommended Concentration Guide (RCG) Values for Radionuclides in Water.............. 5

3 Hazard Measure (HM) for Radionuclides in Spent Fuel and Solidified High-Level Waste .......... 7

4 Hazard Measure (HM) Ranking of Radionuclides . . . . . . 8

5 Overall Hazard Measure Ranking of Radionuclides . . . . . . 9

$6 \quad$ Values of Parameter $F$ in Equation $4 \ldots 17$

7 Comparison between Equation 3 and Results of Hill and Grimwood................. 18

8 Parameters Used in Hill and Grimwood Model. . . . . . . . 20

9 Sorption Distribution Coefficients for Basalt . . . . . 25

10 Transport Hazards of Important Radionuclides. . . . . . . 26

11 Ranking of Key Radionuclides. . . . . . . . . 27 


\section{INTRODUCTION}

High-level nuclear reactor wastes contain a large number of different radionuclides which must be isolated from the biosphere until they decay to innocuous radiation levels. Some of these will decay rapidly after removal from the reactor and will not require long-term isolation. others must be isolated for millions of years. The objective of this report is to identify those radionuclides which appear to pose the greatest potential threat to mankind during storage of nuclear wastes in a repository mined in deep basalt formations. The safety assessment studies required for licensing a repository in basalt will then concentrate on the key radionuclides since these will determine the overall safety of the repository.

The selection of materials and design of engineered barriers depends on the identities of key radionuclides. The backfill, overpack, and buffer barriers between the waste form and repository walls will be designed to contain those radionuclides which have been shown to be mobile in basalt formations. Modeling of radionuclide transport from the repository will also be confined to key radionuclides. This information will then be used to optimize the design of the repository.

\section{CRITERIA USED FOR SELECTION}

The criteria used for identification of key radionuclides were as follows:

- Quantity of radionuclide present in spent reactor fuel and reprocessed waste

- Biologicar toxicity

- Leach rate from the waste form

- Transport rate from the repository to the biosphere.

In addition to these factors, several assumptions were made in order to narrow the list of radionuclides to be considered. For example, only 
those radionuclides which are present in significant quantities 1,000 years after discharge from the reactor are considered. This restriction can generally be applied since the engineered package will probably be required to contain the waste for 1,000 years (USNRC, 1980). Another assumption is that the waste form will be either borosilicate glass containing high-level waste (HLW) or unreprocessed spent fuel.

Various combinations of the above criteria have been used to calculate safety indices for different types of radioactive wastes (Voss, 1979). Safety indices are used to compare the hazards associated with various waste management operations. Each type of index yields specific information for a given operation and most are not applicable to deep geologic storage. This is because they do not take into account the most likely radionuclide release scenario (dissolution of the waste form and transport by groundwater) for a deep repository in basalt. Other indices require more information than is available for calculation. However, the Hazard Measure (HM) is a useful safety index for ranking radionuclides in the wastes according to quantity and biological toxicity. The HM ranking was combined with the transport properties of each radionuclide in basalt formations (including leaching) to obtain an overall ranking of the key radionuclides in a nuclear waste repository in basalt.

\section{QUANTITY OF RADIONUCLIDE IN WASTE}

The quantity of a specific radionuclide in nuclear waste depends on the following factors:

- Reactor type (Light Water Reactor [LWR] or Pressurized Water Reactor $[P W R]$ )

- Time after discharge from the reactor (half-life, production of radioactive daughters)

- Length of time in the reactor or burn-up

- Waste type (reprocessed waste or spent fuel).

Voss (1979) has calculated the quantities of major radionuclides in spent fuel discharged from a typical LWR and solidified high-level reprocessing wastes for decay periods of up to $1,000,000$ years. These quantities were 
calculated using the computer program ORIGEN (Bell, 1973) and were normalized to GW(e) - yr generated. Separation efficiencies of the solvent extraction process were combined with the ORIGEN code to calculate the radionuclide content of solidified high-level waste. The quantities present in each waste form 1,000 years and 1,000,000 years after discharge from the reactor are given in Table 1 . The waste is assumed to be from a typical LWR. Short-lived daughters such as ${ }^{126} \mathrm{Sb}\left(t_{1 / 2}=12.4\right.$ days $)$ which are in secular equilibrium with a long-lived parent are not included in the list.

\section{Biological Toxicity}

The quantity of each radionuclide in the waste is, of course, a basic input to the determination of its potential hazard. However, alone it is not sufficient information to be able to rank the radionuclides in terms of relative hazard. The toxicity to man varies considerably among the radioisotopes. Toxicity, in turn, is dependent on retention of the isotope by the body, radiosensitivity of the contaminated tissue, type of body organ affected, half-life, and energy of radiation produced.

One measure of relative toxicity to man of radionuclides is the recommended concentration guide ( $R C G$ ) values of radioisotope concentrations in water and air (10 CFR 20, Appendix B). These are defined for uncontrolled discharges of both insoluble and soluble radionuclides. Values of RCG are specified so that a "standard man" consuming both contaminated air and water will not exceed his annual dose limit, where the standard man consumes $7,300 \mathrm{~m}^{3} /$ year of air and $0.8 \mathrm{~m}^{3} /$ year of water. Values of RCG for major radionuclides are given in order of decreasing toxicity in Table 2. The allowed concentrations cover a range of about 4 orders of magnitude with ${ }^{226} \mathrm{Ra}$ being the most toxic and ${ }^{93} \mathrm{Zr}$ the least toxic.

A useful and widely used safety index for radionuclide comparisons combines the quantity of radionuclide and toxicity of the radionuclide. The HM is defined as follows:

$$
H M_{i}=Q_{j} / R C G_{j}
$$


RHO-BWI-ST-9

TABLE 1. Major Radionuclides* in Spent Fuel and Solidified High-Level Waste.

\begin{tabular}{|c|c|c|c|c|}
\hline \multirow{3}{*}{ Isotope } & \multicolumn{4}{|c|}{ Quantity, Ci/GW(e)-yr } \\
\hline & \multicolumn{2}{|c|}{ Spent Fuel } & \multicolumn{2}{|c|}{ Solidified High-Level Waste } \\
\hline & 1,000 yrs & $1,000,000$ yrs & 1,000 yrs & $1,000,000$ yrs \\
\hline${ }^{79} \mathrm{Se}$ & $1.3 \mathrm{E}+1$ & $3.1 E-4$ & $1.3 E+1$ & $3.0 \mathrm{E}-4$ \\
\hline${ }^{87} \mathrm{Rb}$ & $6.5 E-4$ & $6.5 E-4$ & $6.1 E-4$ & $6.1 \mathrm{E}-4$ \\
\hline${ }^{90} \mathrm{Sr}$ & $5.0 \mathrm{E}-5$ & -- & $4.5 E-5$ & -- \\
\hline${ }^{93} \mathrm{Zr}$ & $6.5 E+1$ & $4.2 E+1$ & $6.0 E+1$ & $3.8 E+1$ \\
\hline $93 m_{N b}$ & $6.5 E+1$ & $4.2 E+1$ & $6.0 \mathrm{E}+1$ & $3.8 E+1$ \\
\hline${ }^{99} \mathrm{TC}$ & $5.0 \mathrm{E}+2$ & $1.9 E+1$ & $4.9 E+2$ & $1.9 E+1$ \\
\hline${ }^{107} \mathrm{Pd}$ & 3.8 & 3.4 & 4.5 & 4.2 \\
\hline${ }^{126} \mathrm{Sn}$ & $1.8 \mathrm{E}+1$ & $1.8 \mathrm{E}-2$ & $2.0 E+1$ & $2.0 \mathrm{E}-2$ \\
\hline${ }^{129} \mathrm{I}$ & 1.3 & 1.3 & $6.7 E-3$ & $6.5 E-3$ \\
\hline${ }^{135} \mathrm{Cs}$ & $1.0 \mathrm{E}+1$ & 8.0 & $1.2 \mathrm{E}+1$ & 9.5 \\
\hline${ }^{137} \mathrm{Cs}$ & $3.4 \mathrm{E}-4$ & -- & $3.3 E-4$ & -- \\
\hline${ }^{151} \mathrm{Sm}$ & $1.5 E+1$ & -- & $1.6 \mathrm{E}+1$ & - \\
\hline $166_{\text {Ho }}$ & $1.1 \mathrm{E}-2$ & -- & $1.4 E-2$ & -- \\
\hline${ }^{210} \mathrm{~Pb}$ & $3.8 \mathrm{E}-2$ & $1.4 E+1$ & 1.1 E-5 & $1.8 \mathrm{E}-3$ \\
\hline${ }^{226} \mathrm{Ra}$ & $3.8 \mathrm{E}-2$ & $1.4 E+1$ & $1.1 \mathrm{E}-5$ & $1.8 \mathrm{E}-3$ \\
\hline${ }^{230} \mathrm{Th}$ & $2.3 E-1$ & $1.4 \mathrm{E}+1$ & $6.8 \mathrm{E}-1$ & $1.9 \mathrm{E}+1$ \\
\hline $233 u$ & $1.1 \mathrm{E}-1$ & $3.3 \mathrm{E}+1$ & $1.8 \mathrm{E}-5$ & $5.3 \mathrm{E}-3$ \\
\hline $234 U$ & $3.1 E+1$ & $1.3 E+1$ & 9.2 E-3 & $1.7 \mathrm{E}-3$ \\
\hline $238 u$ & $1.2 \mathrm{E}+1$ & $1.2 E+1$ & $1.2 E-3$ & $1.2 \mathrm{E}-3$ \\
\hline${ }^{237} \mathrm{~Np}$ & $3.6 E+1$ & $3.1 E+1$ & 2.9 & 2.5 \\
\hline${ }^{239} \mathrm{Pu}$ & $1.1 E+4$ & $4.6 E-6$ & $1.3 E+1$ & $6.5 E-8$ \\
\hline${ }^{242} \mathrm{Pu}$ & $6.1 \mathrm{E}+1$ & 9.9 & $1.5 \mathrm{E}-1$ & $2.4 E-2$ \\
\hline${ }^{241}{ }_{A m}$ & $3.2 E+4$ & -- & $4.7 E+3$ & -- \\
\hline${ }^{243} \mathrm{Am}$ & $5.0 E+2$ & 4.6 E-6 & $1.6 E+3$ & $6.5 \mathrm{E}-5$ \\
\hline${ }^{245} \mathrm{Cm}$ & 6.5 & -- & $6.5 E+1$ & -- \\
\hline
\end{tabular}

*For most actinides, only the isotopes with the greatest activity/GW(e)-yr are given. 
RHO-BWI-ST-9

TABLE 2. Recommended Concentration Guide (RCG) Values for Radionuclides in Water.

\begin{tabular}{|c|c|c|c|}
\hline I sotope & $\operatorname{RCG}\left(\mathrm{Ci} / \mathrm{m}^{3}\right)$ & Isotope & $\operatorname{RCG}\left(\mathrm{Ci} / \mathrm{m}^{3}\right)$ \\
\hline${ }^{226} \mathrm{Ra}$ & $3 E-8$ & $245 \mathrm{~cm}$ & $4 E-6$ \\
\hline${ }^{129} 9_{I}$ & $6 E-8$ & ${ }^{239} \mathrm{pu}_{\mathrm{u}}$ & $5 E-6$ \\
\hline $210 \mathrm{pb}$ & $1 \mathrm{E}-7$ & $242 p u$ & $5 E-6$ \\
\hline${ }^{90} \mathrm{Sr}$ & $3 E-7$ & ${ }^{137} \mathrm{Cs}$ & $2 E-5$ \\
\hline${ }^{230} \mathrm{Th}$ & $2 E-6$ & $233 U$ & $3 E-5$ \\
\hline${ }^{237} \mathrm{~Np}$ & $3 E-6$ & $234 U$ & $3 E-5$ \\
\hline${ }^{107} \mathrm{Pd}$ & $3 E-6$ & $166 \mathrm{~m}_{\mathrm{Ho}}$ & $3 E-5$ \\
\hline${ }^{79} \mathrm{Se}$ & $3 E-6$ & $238 U$ & $4 E-5$ \\
\hline $126 s n$ & $3 E-6$ & ${ }^{135} \mathrm{Cs}$ & $1 E-4$ \\
\hline $241_{A m}$ & $4 E-6$ & $87_{\mathrm{Rb}}$ & $1 E-4$ \\
\hline \multirow[t]{4}{*}{${ }^{243} \mathrm{Am}$} & $4 E-6$ & ${ }^{99} \mathrm{Tc}$ & $2 E-4$ \\
\hline & & ${ }^{15} 1_{\mathrm{Sm}}$ & $4 E-4$ \\
\hline & & $93 m_{N b}$ & $4 E-4$ \\
\hline & & & $8 E-4$ \\
\hline
\end{tabular}


where $Q_{j}$ is the quantity in curies, and $R C G_{j}$ is the recommended concentration of some radionuclide, $i$. The $H M$ is given in terms of $\mathrm{m}^{3}$ of air or water. This is the volume of air or water required to reduce the concentration of a radionuclide to the maximum permissible.

Values of HM for major radionuclides in spent fuel and solidified waste at 1,000 years and 1,000,000 years are shown in Table 3. The radionuclides are ranked in order of decreasing HM in Table 4. An overall ranking of the radionuclides was calculated by adding the rankings of individual radionuclides from the four columns given in Table 4 . No weighting factors were applied. The overall HM ranking of the radionuclides is shown in Table 5 . Several radionuclides appear relatively high in this ranking which previously have not been considered very important in safety assessment studies. These are ${ }^{107} \mathrm{Pd},{ }^{230} \mathrm{Th}$,

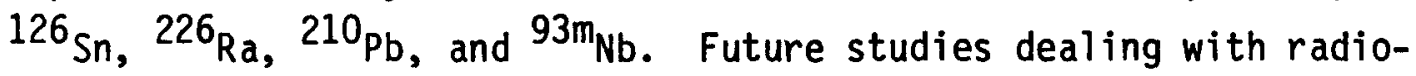
nuclide transport in groundwater should include these radionuclides.

\section{Waste Form Leaching}

The potential hazards to life from a geologic repository depend, of course, on the possible leakage rates of radionuclides in the future. Given that the waste form becomes exposed to a solution by which it can be leached, the rate of nuclide release will depend on the nature of the waste form and the chemical composition of the solution.

A considerable number of experiments have been performed on the rates at which radionuclides may be leached from various waste forms. The most studied waste forms are borosilicate glass containing reprocessed HLW and unreprocessed spent fueT. Ceramic materials such as SYMROC (Ringwood, et al., 1979) have been suggested as potentially better immobilizers of HLW than $\mathrm{glass}$, but as yet there are few experiments to support or refute these claims. This report will, therefore, address only the leaching of HLW--containing $g l$ ass and spent fuel. 
RHO-BWI-ST-9

TABLE 3. Hazard Measure (HM) for Radionuclides in Spent Fuel and Solidified High-Level Waste.

\begin{tabular}{|c|c|c|c|c|}
\hline \multirow{3}{*}{ Isotope } & \multicolumn{4}{|c|}{$H M, m^{3}$} \\
\hline & \multicolumn{2}{|c|}{ Spent Fue 1} & \multicolumn{2}{|c|}{ Solidified High-Level Waste } \\
\hline & 1,000 yrs & $1,000,000$ yrs & 1,000 yrs & $1,000,000$ yrs \\
\hline${ }^{79} \mathrm{Se}$ & $4.3 E+6$ & $1.0 E+2$ & $4.3 E+6$ & $1.0 E+2$ \\
\hline${ }^{87} \mathrm{Rb}$ & 6.5 & 6.5 & 6.1 & 6.1 \\
\hline${ }^{90} \mathrm{Sr}$ & $1.7 E+2$ & -- & $1.5 E+2$ & -- \\
\hline $93 \mathrm{Zr}$ & $8.1 E+4$ & $5.2 E+4$ & $7.5 E+4$ & $4.8 E+4$ \\
\hline $93 m_{N b}$ & $1.6 E+5$ & $1.1 E+5$ & $3.8 E+4$ & $2.4 E+4$ \\
\hline${ }^{99} \mathrm{TC}$ & $2.5 E+6$ & $1.0 \mathrm{E}+5$ & $2.5 E+6$ & $9.5 E+4$ \\
\hline${ }^{107} \mathrm{Pd}$ & $1.3 \mathrm{E}+6$ & $1.1 E+6$ & $1.5 E+6$ & $1.4 E+6$ \\
\hline${ }^{126} \mathrm{Sn}$ & $6.0 E+6$ & $6.0 E+3$ & $6.7 E+6$ & $6.7 E+3$ \\
\hline${ }^{129} \mathrm{I}$ & $2.1 E+7$ & $2.1 E+7$ & $1.1 E+5$ & $1.1 E+5$ \\
\hline${ }^{135} \mathrm{Cs}$ & $1.0 E+5$ & $8.0 E+4$ & $1.2 E+5$ & $9.5 E+4$ \\
\hline${ }^{137}$ Cs & $1.7 E+1$ & -- & $1.7 E+1$ & -- \\
\hline${ }^{151} \mathrm{Sm}$ & $3.7 E+4$ & -- & $4.0 E+4$ & -- \\
\hline $166 \mathrm{~m}_{\mathrm{Ho}}$ & $3.7 E+3$ & -- & $4.7 E+1$ & -- \\
\hline $210 \mathrm{~Pb}$ & $3.8 E+5$ & $1.4 E+8$ & $1.1 E+2$ & $1.8 \mathrm{E}+4$ \\
\hline${ }^{226} \mathrm{Ra}$ & $1.3 \mathrm{E}+6$ & $4.7 E+8$ & $3.7 E+2$ & $6.0 \mathrm{E}+4$ \\
\hline${ }^{230} T h$ & $1.2 E+5$ & $7.0 E+6$ & $3.4 E+5$ & $9.5 E+6$ \\
\hline${ }^{233} U$ & $3.7 E+3$ & $1.1 E+6$ & 0.6 & $1.8 E+2$ \\
\hline${ }^{234} U$ & $1.0 E+6$ & $4.3 E+5$ & $3.1 E+2$ & $5.6 E+1$ \\
\hline $238 U$ & $3.0 E+5$ & $3.0 E+5$ & $3.0 \mathrm{E}+1$ & $3.0 \mathrm{E}+1$ \\
\hline${ }^{237} \mathrm{~Np}$ & $1.2 E+7$ & $1.0 \mathrm{E}+7$ & $9.6 E+5$ & $8.3 E+5$ \\
\hline${ }^{239} \mathrm{Pu}$ & $2.2 E+9$ & 0.9 & $2.6 E+6$ & $1.3 \mathrm{E}-2$ \\
\hline $242 p_{u}$ & $1.2 \mathrm{E}+7$ & $2.0 E+6$ & $3.0 E+4$ & $4.8 E+3$ \\
\hline${ }^{241} \mathrm{Am}$ & $8.0 E+10$ & -- & $1.2 E+9$ & -- \\
\hline${ }^{243} \mathrm{Am}$ & $1.3 E+8$ & 1.2 & $4.0 E+8$ & $1.6 \mathrm{E}+1$ \\
\hline $245 \mathrm{~cm}$ & $1.6 E+6$ & -- & $1.6 E+7$ & -- \\
\hline
\end{tabular}


RHO-BWI-ST-9

TABLE 4. Hazard Measure (HM) Ranking of Radionuclides.

\begin{tabular}{|c|c|c|c|}
\hline \multicolumn{2}{|c|}{ Spent Fuel } & \multicolumn{2}{|c|}{ Solidified High-Level Waste } \\
\hline 1,000 yrs & $1,000,000$ yrs & 1,000 yrs & $1,000,000 \mathrm{yrs}$ \\
\hline $\begin{array}{c}{ }^{241} \mathrm{Am} \\
{ }^{239} \mathrm{Pu} \\
{ }^{243} \mathrm{Am} \\
{ }^{129} \mathrm{I} \\
{ }^{237} \mathrm{~Np} \\
{ }^{242} \mathrm{Pu} \\
{ }^{126} \mathrm{Sn} \\
{ }^{79} \mathrm{Se} \\
{ }^{99} \mathrm{Tc} \\
{ }^{245} \mathrm{Cm} \\
107 \mathrm{Pd} \\
226_{\mathrm{Ra}} \\
234 \mathrm{U} \\
210 \mathrm{~Pb} \\
238_{\mathrm{U}} \\
230 \mathrm{Th} \\
93 \mathrm{~m}_{\mathrm{Nb}} \\
135 \mathrm{Cs} \\
93 \mathrm{Zr} \\
151_{\mathrm{Sm}} \\
166 \mathrm{~m}_{\mathrm{Ho}} \\
233_{\mathrm{U}} \\
90 \mathrm{Sr} \\
137 \mathrm{Cs} \\
87_{\mathrm{Rb}}\end{array}$ & $\begin{array}{l}{ }^{226} \mathrm{Ra} \\
210 \mathrm{~Pb} \\
{ }^{129} \mathrm{I} \\
237 \mathrm{~Np} \\
{ }^{230} \mathrm{Ph} \\
242 \mathrm{Pu} \\
107 \mathrm{Pd} \\
233 \mathrm{U} \\
234 \mathrm{U} \\
238 \mathrm{U} \\
{ }^{93 m_{\mathrm{Pb}}} \\
{ }^{99} \mathrm{Tc} \\
{ }^{135} \mathrm{Cs} \\
{ }^{93} \mathrm{Zr} \\
{ }^{126} \mathrm{Sn} \\
79 \mathrm{Se} \\
{ }^{87} \mathrm{Rb} \\
243 \mathrm{Am} \\
239 \mathrm{Pu}\end{array}$ & $\begin{array}{c}{ }^{241} \mathrm{Am} \\
{ }^{243} \mathrm{Am} \\
{ }^{245} \mathrm{Cm} \\
{ }^{126} \mathrm{Sn} \\
{ }^{79} \mathrm{Se} \\
{ }^{239} \mathrm{Pu} \\
{ }^{99} \mathrm{Tc} \\
{ }^{107} \mathrm{Pd} \\
{ }^{237} \mathrm{~Np} \\
{ }^{230} \mathrm{Th} \\
{ }^{135} \mathrm{Cs} \\
{ }^{129} \mathrm{I} \\
{ }^{93} \mathrm{Zr} \\
151_{\mathrm{Sm}} \\
{ }^{93 m_{\mathrm{Nb}}} \\
242 \mathrm{Pu} \\
226 \mathrm{Ra} \\
234 \mathrm{U} \\
{ }^{90} \mathrm{Sr} \\
210 \mathrm{~Pb} \\
166 \mathrm{~m}_{\mathrm{Ho}} \\
238 \mathrm{U} \\
137 \mathrm{Cs} \\
{ }^{87} \mathrm{Rb} \\
233 \mathrm{U}\end{array}$ & $\begin{array}{c}{ }^{230} \mathrm{Th} \\
107 \mathrm{Pd} \\
237 \mathrm{~Np} \\
{ }^{129} \mathrm{I} \\
{ }^{135} \mathrm{Cs} \\
{ }^{99} \mathrm{Tc} \\
{ }^{226} \mathrm{Ra} \\
93{ }^{9 \mathrm{rr}} \\
93 \mathrm{~m}_{\mathrm{Nb}} \\
210 \mathrm{~Pb} \\
126 \mathrm{Sn} \\
242 \mathrm{Pu} \\
233 \mathrm{U} \\
79 \mathrm{Se} \\
234 \mathrm{U} \\
238 \mathrm{U} \\
243 \mathrm{Am} \\
87_{\mathrm{Rb}} \\
239_{\mathrm{Pu}}\end{array}$ \\
\hline
\end{tabular}


RHO-BWI -ST-9

TABLE 5. Overall Hazard Measure (HM) Ranking of Radionuclides.

\begin{tabular}{|c|c|}
\hline Rank & Radionuclide \\
\hline 1 & $237_{\mathrm{Np}}$ \\
\hline 2 & ${ }^{129} \mathrm{I}$ \\
\hline 3 & ${ }^{107} \mathrm{Pd}$ \\
\hline $4 *$ & ${ }^{230} \mathrm{Th}$ \\
\hline $4 \star$ & ${ }^{99} \mathrm{TC}$ \\
\hline 6 & ${ }^{226} \mathrm{Ra}$ \\
\hline 7 & ${ }^{126} S_{S n}$ \\
\hline 8 & ${ }^{242} p_{u}$ \\
\hline 9 & ${ }^{243} \mathrm{Am}$ \\
\hline 10 & ${ }^{79} \mathrm{Se}$ \\
\hline $11 *$ & ${ }^{239} \mathrm{Pu}$ \\
\hline $11 *$ & $210_{\mathrm{Pb}}$ \\
\hline 13 & ${ }^{135} \mathrm{Cs}$ \\
\hline 14 & ${ }^{241} A m$ \\
\hline 15 & $93 m_{N b}$ \\
\hline 16 & $93 Z r$ \\
\hline 17 & $234_{U}$ \\
\hline 18 & ${ }^{245} \mathrm{Cm}$ \\
\hline 19 & ${ }^{238} \mathrm{U}$ \\
\hline 20 & $233_{U}$ \\
\hline 21 & ${ }^{151_{S m}}$ \\
\hline 22 & ${ }^{87} \mathrm{Rb}$ \\
\hline $23 *$ & ${ }^{90} \mathrm{Sr}$ \\
\hline $23 *$ & $166 \mathrm{~m}_{\mathrm{Ho}}$ \\
\hline
\end{tabular}

*Tie in ranking. 
Leaching of Glass Waste Forms. The rate of leaching of silicate and borosilicate glasses in contact with water depends on temperature, $\mathrm{pH}$, and the composition of the solution (Bradley, et al., 1979). Most leaching experiments performed thus far have not, however, addressed the possible variations of these parameters and do not enable exact calculations of leach rates in a basalt environment. Transport modeling must, therefore, make use of approximate leach rates derived from dissolution of the waste form in deionized water. Bradley (1978) and Bradley, et al. (1979) have found that the leach rates from borosilicate glasses depend greatly on the element concerned. At $22^{\circ} \mathrm{C}$, values of apparent leach rate of the glass matrix varied from $4 \times 10^{-5} \mathrm{~g} \mathrm{~cm}^{-2} \mathrm{day}^{-1}$ (based on cesium) to $4 \times 10^{-9} \mathrm{~g} \mathrm{~cm}^{-2}$ day $^{-1}$ (based on curium). Leach rates decreased with time in experiments of up to 1.75 years' duration and indicated a gradual change from a diffusion-controlled to an interface-controlled dissolution mechanism (Bradley, 1978).

Above $22^{\circ} \mathrm{C}$, leach rate increases by about an order of magnitude for each $50^{\circ} \mathrm{C}$ increase in temperature ( $\mathrm{Hill}$ and Grimwood, 1978); this effect will obviously be of importance at Hanford where the temperature of leaching would be $65^{\circ} \mathrm{C}$ or more.

Leaching of Spent Fuel. Katayama (1976) investigated the leaching of $\mathrm{UO}_{2}$ fuel pellets in Hanford groundwater and in deionized water at $25^{\circ} \mathrm{C}$. The leach rates showed a similar range to those observed in the glass leaching experiments and depended on the element under investigation. Leach rates, at atmospheric oxygen pressure varied from $5 \times 10^{-6} \mathrm{~g} \mathrm{~cm}^{-2} \mathrm{day}^{-1}$ (for ${ }^{137} \mathrm{Cs}$ ) to $4 \times 10^{-9} \mathrm{~g} \mathrm{~cm}^{-2} \mathrm{day}^{-1}$ (for ${ }^{244} \mathrm{Cm}$ ). As in the case of borosilicate glass, these leach rates should increase with increasing temperature. They should also be considerably affected by Eh and carbonate content of the leaching solution. The latter effects are due to the stability of the 6+ oxidation state of uranium and the ready formation of carbonate complexes of this ion (Langmuir, 1978).

In view of the uncertainties and wide range of leach rate values obtained experimentally, it is impossible to make precise estimates of the leaching characteristics of different waste forms in a potential nuclear waste repository at Hanford. Leach rates for spent fuel and 
borosilicate glass are comparable at $25^{\circ} \mathrm{C}$, but readily soluble elements such as cesium and rubidium are much more rapidly leached from spent fuel at $100^{\circ} \mathrm{C}$ (Scheetz, et al., 1979). Both waste forms exhibit changing dissolution mechanisms with time, glass probably approaching steady-state interface-controlled kinetics. If such a mechanism applies, then over long time periods dissolution of the waste form should be essentially congruent and all elements should be removed at the same rate. Bearing these observations in mind, and considering temperatures on the order of $100^{\circ} \mathrm{C}$, a value of $10^{-5} \mathrm{~g} \mathrm{~cm}^{-2} \mathrm{day}^{-1}$ was used in the transport model described in the following section.

\section{Transport Properties}

In order for any leachable radionuclide to constitute a potential hazard, there must be a mechanism to transport it from the repository to the biosphere. With the exception of improbable catastrophic events such as volcanism or meteor impact, the fastest likely path to the biosphere is in solution or suspension in flowing water. This mechanism, which has been the subject of considerable analysis in recent years, can be used to place some constraints on the discharge rates of specific radionuclides to the environment. It thus provides an additional method of screening nuclides and estimating the relative hazard which each constitutes.

The complete analysis of transport through heterogeneous layered media requires, of course, numerical modeling with the aid of complex computer codes and considerable efforts are being made to develop precise models of radionuclide release from geologic repositories. If the properties of the geologic media are very simple and flow is one-dimensional, however, the transport equations can be solved analytically without recourse to numerical methods. The results of such approaches do not give precise discharge rates from a geologic repository. They do, however, enable analysis of the sensitivity of discharge rates to variation of the controlling parameters. For the purpose of this document, therefore, the simple analytic method will point out the most important factors controlling radionuclide migration. 
Possible Controls on Transport. As has been discussed earlier, the release rate of radionuclides to the environment has substantial dependence on the rate at which the waste form leaches. Given that any particular waste form is leachable, the rate of accumulation in the biosphere and the time at which the nuclide starts to discharge will depend on:

1. Retardation due to sorption on the geologic medium

2. Porosity and permeability of the geologic medium

3. Radionuclide dispersion in the aqueous medium

4. Velocity of water flow

5. Path length from repository to environment.

Factors 1 to 3 will be discussed in the context of establishment of a simple transport model. Factors 4 and 5 will only be discussed when the results of the model are related.

Retardation Due to Sorption. As water flows through a porous medium, the process of re-equilibration between aqueous and solid phases takes place continuously. If the water is rich in elements which are absent or present in very low concentrations in the rock, then the re-equilibration process will involve removal of some quantity of each element via sorption on the solids. For the purpose of modeling the rate of transport of radionuclides, it is convenient to define a retardation factor due to sorption. The retardation factor ( $R$ ) is the ratio of water velocity to nuclide velocity and may be calculated from:

$$
R=1+K_{d} \frac{\rho}{\phi}
$$

where

$$
\begin{aligned}
K_{d} & =\begin{array}{l}
\text { activity per unit mass sorbed/activity per unit volume in } \\
\text { solution }
\end{array} \\
\rho & =\text { density of rock; } \\
\phi & =\text { fraction of voids in the rock. }
\end{aligned}
$$

The retardation factor and the rate of nuclide migration are thus directly related to the sorption distribution coefficient $k_{d}$. The 
value of $K_{d}$ varies over many orders of magnitude depending on the nuclide, nature of the sorbing medium, solution composition, and temperature. The transport model should enable the influence of $k_{d}$ on radionuclide discharge rates to be calculated.

Porosity and Permeability of the Geologic Media. Equation 2 shows that the retardation factor is inversely proportional to the porosity of the geologic medium through which the nuclides pass. It is thus apparent that the influence of porosity on $R$ is as great as that of $K_{d}$ and that porosity must be known as accurately as possible if a valid model is to be derived.

The influence of permeability on nuclide migration may be qualitatively appreciated from Darcy's Law. For a fixed hydraulic gradient, this states that the rate of water flow and, hence, the water velocity is directly proportional to the permeability of the rock. Thus, permeability also has a direct influence on the rate of nuclide migration.

Dispersion of the Radionuclide. The radionuclide disperses in the aqueous medium due to a combination of the effects of mechanical mixing and molecular diffusion. The ratio of the dispersion coefficient to groundwater velocity $(\alpha / v)$ is the characteristic dispersive length of the geologic medium and is an approximate measure of its heterogeneity. In granular, well-compacted rocks, the dispersive length can vary from a few centimeters to a few meters; whereas in fissured rocks, values up to $100 \mathrm{~m}$ can occur (Zuber, 1974). The effects of such variations on peak radionuclide discharge rates are not immediately obvious and need to be analyzed with the aid of a transport model.

One-Dimensional Transport Equation. Assuming constant values of dispersion coefficient $(\alpha)$, velocity $(v)$, and retardation factor $R$, the one-dimensional transport equation is:

$$
\alpha \frac{\partial^{2} C}{\partial x}-v \frac{\partial C}{\partial x}-R \frac{\partial C}{\partial t}-R \lambda c=0 .
$$

In this equation, $c$ is the radionuclide concentration, $x$ distance, the decay constant, and $t$ time. Hadermann (1980) has solved this equation for the case of band radionuclide release in which rate of release is 
constant throughout the period of waste dissolution (Figure 1). A physically more realistic case would involve a decaying release rate as leaching decreases with time (Figure 1). If the geologic medium initially contains none of the radionuclide and if it is infinitely dilute at the boundary with the environment, the solution may be represented by the simple equation:

$$
C_{x, t}=\frac{C_{0}}{2}(F) \exp (-\lambda t)
$$

$C_{x, t}$ is the concentration at distance $x$ from the repository at time $t$. $C_{0}$ is the initial concentration and $F$ is a parameter which depends on time, distance, velocity, dispersion, and retardation. $F$ is a sum of four error function complements, the exact form of which is omitted for simplicity. The interested reader is referred to Hadermann (1980) for details.

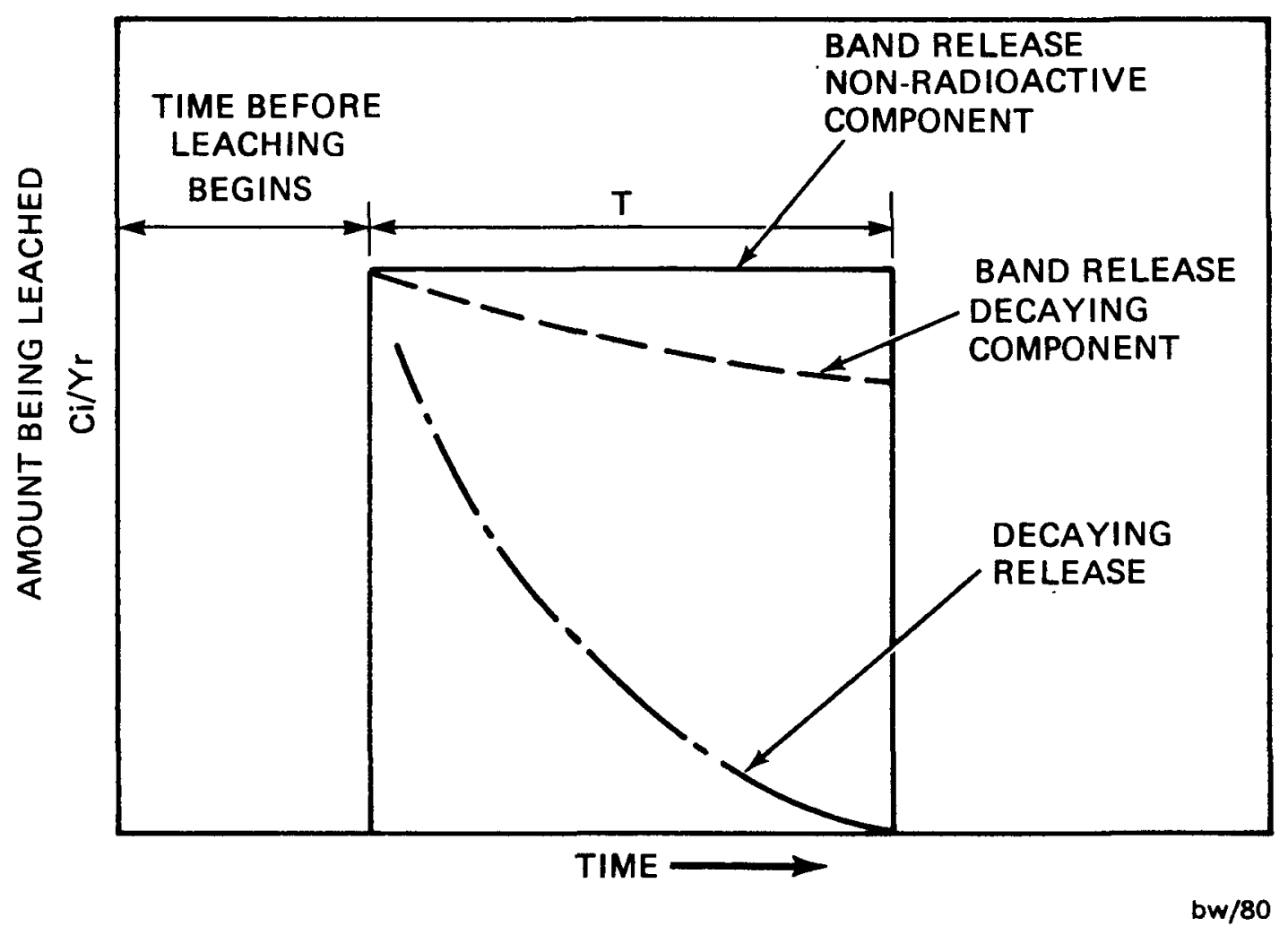

FIGURE 1. Band Release and Decaying Release Models for Radionuclide Release from a Repository. 
On inspection of the form of $F$, it becomes clear that there are a number of simple relationships between the transport properties which govern its magnitude. The first is that there is a characteristic transport time, $t_{c}$, which is the time after leaching begins that the radionuclide discharge rate to the environment, at distance $x$, peaks. The time of peak discharge is given by:

$$
t_{c}=\frac{x R}{v} \text {. }
$$

This expression may be applied to nuclides such as fission products which decay, but are not formed in the rock column. This situation is more complex for actinides which are generated during transport, but, as will be shown below, some reasonable approximations can be made. The other simple relationship which exists is that $F$ can be tabulated as a function of just two parameters:

$$
\frac{t_{c}-T}{t_{c}} \text { and } \frac{x v}{\alpha}
$$

where $T$ is the overall time of leaching of the waste. values of $F$ are tabulated in Table 6. It should be noted that as $\frac{t_{c}-T}{t_{c}}$ approaches $1, F$ approaches

$$
\frac{T}{2 t_{c}} \cdot \sqrt{\frac{x v}{\alpha}} .
$$

Model Testing. The analytical solution was checked for consistency with the numerical model of $\mathrm{Hill}$ and Grimwood (1978). Apart from the fact that these authors used a decaying release model (see Figure 1), the results for fission products should be similar.

Figure 2 is reproduced from the work of $\mathrm{Hill}$ and Grimwood (1978) and illustrates the direct effect of retardation on the time of peak discharge. It is also shown in Figure 2 that if $t_{c}$ is greater than the leaching time, $T$ (about 3,500 years), the concentration decays rapidly with time past the peak. A comparison of $t_{c}$ 's and peak concentrations obtained by $\mathrm{Hill}$ and Grimwood (1978) with those calculated here are given in Table 7. As can be seen, for the system parameters given in Table 8, agreement between the results is good. 
RHO-BWI-ST-9

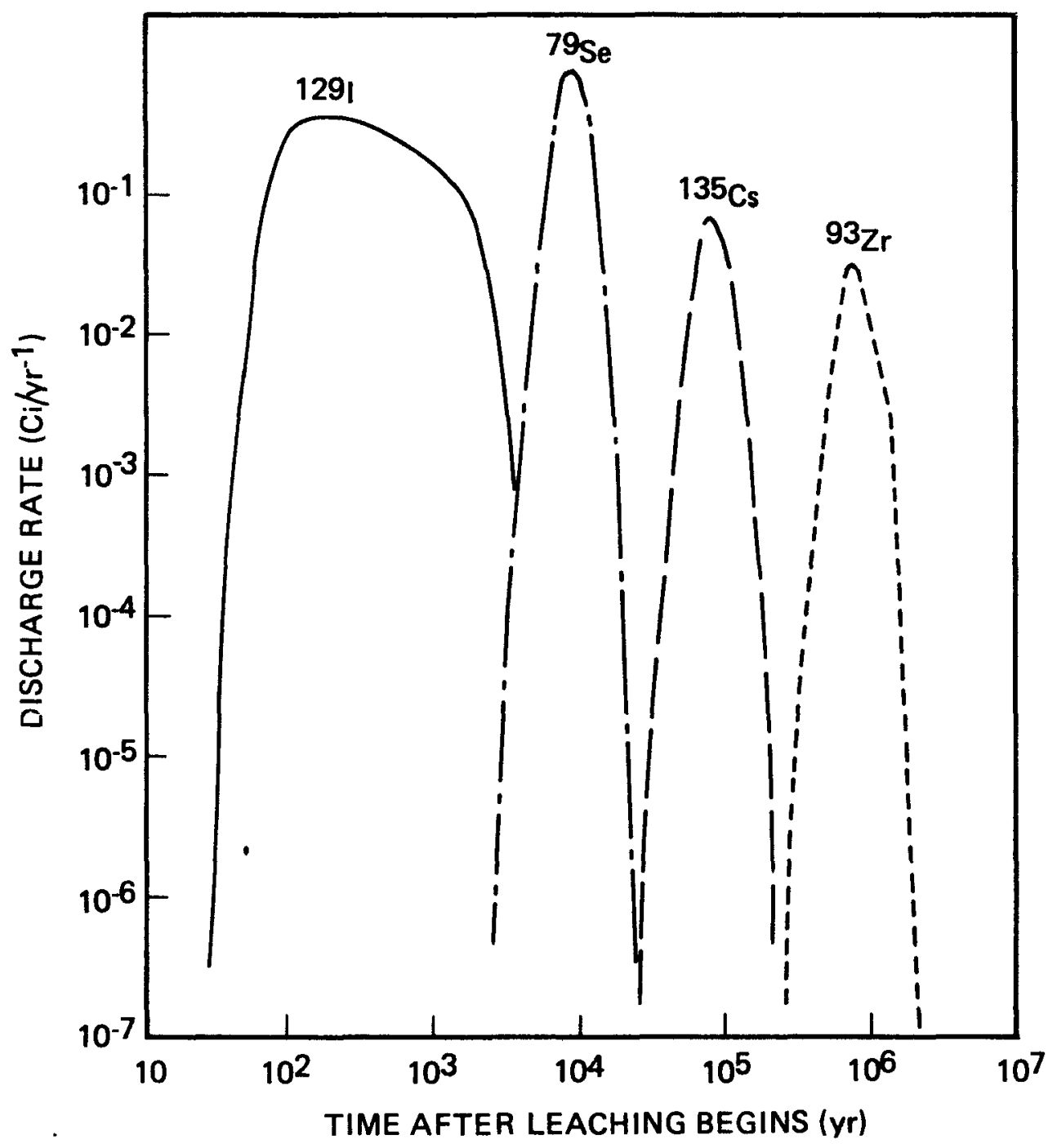

FIGURE 2. Discharge Rates of ${ }^{79} \mathrm{Se},{ }^{93} \mathrm{Zr},{ }^{129} \mathrm{I},{ }^{135} \mathrm{Cs}$. 
RHO-BWI-ST-9

TABLE 6. Values of Parameter $F$ in Equation 4.

\begin{tabular}{l|c|c|c|c|c|c|c}
\hline $\mathrm{t}_{c^{-T}}$ & \multicolumn{7}{|c}{ Distance/Dispersive Length $\frac{x v}{\alpha}$} \\
\cline { 2 - 8 } $\mathrm{t}_{\mathrm{c}}$ & 1 & 4 & 10 & 100 & 1,000 & 10,000 & $10^{5}$ \\
\hline 0 & 1.43 & 1.26 & 1.17 & 1.06 & 1.02 & 1.01 & 1.00 \\
0.5 & 0.45 & 0.80 & 1.01 & 1.06 & 1.02 & 1.01 & 1.00 \\
0.7 & 0.22 & 0.43 & 0.64 & 1.05 & 1.02 & 1.01 & 1.00 \\
0.9 & 0.06 & 0.13 & 0.19 & 0.48 & 1.01 & 1.01 & 1.00 \\
0.95 & 0.03 & 0.06 & 0.09 & 0.29 & 0.75 & 1.01 & 1.00 \\
0.99 & 0.005 & 0.011 & 0.016 & 0.058 & 0.18 & 0.52 & 0.98 \\
\hline
\end{tabular}

Actinide Chains. The modeling of the discharge rates of actinides using Equation 4 is complicated by the fact that most of the relevant nuclides are being generated, as well as decaying during transport. For nuclides which are at the beginning of decay chains, however, Equation 4 holds as well as it does for fission products (e.g., ${ }^{247} \mathrm{Cm}$ in Table $7 \mathrm{~b}$ ). The equation also applies to those nuclides for which the precursor concentrations in the waste form are very low [case (a)]. This is illustrated with respect to ${ }^{242} \mathrm{Pu},{ }^{237} \mathrm{~Np}$, and ${ }^{238} \mathrm{U}$ in the table.

In addition to the simple cases outlined above, three additional actinide cases will be considered.

Case $b \quad t_{1 / 2}$ approximately equals $t_{f}$, high concentration of at least one precursor; e.g., ${ }^{234} \mathrm{U}, 233 \mathrm{U}$

Case $c \quad t_{1 / 2}<t_{c}$, low concentrations of all precursors; e.g., $238 \mathrm{Pu}$.

Case $d t_{1 / 2}<t_{c}$, high concentration of at least one precursor;

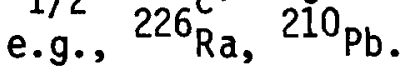


RHO-BWI-ST-9

TABLE 7a. Comparison Between Equation 3 and Results of Hill and Grimwood (1979).

\begin{tabular}{|c|c|c|c|c|c|}
\hline \multicolumn{6}{|c|}{ Fission Products } \\
\hline \multirow{2}{*}{ Nuclide } & \multirow{2}{*}{$\begin{array}{l}\text { Initial } \\
\text { Inventory, } \mathrm{C} i\end{array}$} & \multicolumn{2}{|c|}{$\begin{array}{l}\text { Peak Discharge Rate } \\
\text { Ci/yrs }\end{array}$} & \multicolumn{2}{|c|}{$t_{c} y r$} \\
\hline & & $a$ & b & a & b \\
\hline${ }^{79} \mathrm{Se}$ & $4.4 \times 10^{3}$ & 0.8 & 0.7 & 10,000 & 9,000 \\
\hline $87 \mathrm{Rb}$ & $2.2 \times 10^{-1}$ & $9 \times 10^{-6}$ & $10^{-5}$ & 40,000 & 50,000 \\
\hline $93 \mathrm{Zr}$ & $2.1 \times 10^{4}$ & 0.03 & 0.07 & $9 \times 10^{5}$ & $9 \times 10^{5}$ \\
\hline${ }^{99} \mathrm{TC}$ & $1.5 \times 10^{5}$ & 100 & 84 & 200 & 90 \\
\hline $107 \mathrm{pd}$ & $1.2 \times 10^{3}$ & 0.02 & 0.05 & $10^{5}$ & $10^{5}$ \\
\hline${ }^{126} \mathrm{Sn}$ & $6.1 \times 10^{3}$ & 0.06 & 0.12 & $10^{5}$ & $10^{5}$ \\
\hline${ }^{129} \mathrm{I}$ & $4.2 \times 10^{2}$ & 0.3 & 0.2 & 200 & 90 \\
\hline${ }^{135} \mathrm{cs}$ & $3.2 \times 10^{3}$ & 0.06 & 0.14 & $9 \times 10^{4}$ & $9 \times 10^{4}$ \\
\hline
\end{tabular}

aHill and Grimwood (1978).

bThis work. 
RHO-BWI-ST-9

TABLE 7b. Comparison Between Equation 3 and Results of Hill and Grimwood (1979).

\begin{tabular}{|c|c|c|c|c|c|}
\hline \multicolumn{6}{|c|}{ Actinides } \\
\hline \multirow{2}{*}{ Nuclide } & \multirow{2}{*}{$\begin{array}{c}\text { Initial } \\
\text { Inventory, } \mathrm{Ci}\end{array}$} & \multicolumn{2}{|c|}{$\begin{array}{l}\text { Peak Discharge Rate } \\
\text { Ci/yrs }\end{array}$} & \multicolumn{2}{|c|}{$t_{c} y r$} \\
\hline & & a & b & a & b \\
\hline $238 U$ & 18 & $3 \times 10^{-5}$ & $6 \times 10^{-5}$ & $10^{6}$ & $1.3 \times 10^{6}$ \\
\hline $237 \mathrm{~Np}$ & $3.8 \times 10^{3}$ & 0.8 & 0.6 & $10^{4}$ & 9,000 \\
\hline $242 \mathrm{pu}$ & 76 & $4 \times 10^{-5}$ & $9 \times 10^{-5}$ & $8 \times 10^{5}$ & $9 \times 10^{5}$ \\
\hline${ }^{247} \mathrm{Cm}$ & $3.1 \times 10^{-3}$ & $2 \times 10^{-8}$ & $9 \times 10^{-8}$ & $3 \times 10^{5}$ & $3 \times 10^{5}$ \\
\hline \multicolumn{6}{|c|}{ Case $b$ Long $t_{\frac{1}{2}}$, high concentration of one precursor } \\
\hline $233 v$ & 0.96 & $10^{-4}$ & $10^{-4}$ & $2 \times 10^{4}$ & 9,000 \\
\hline $234 u$ & 73 & $6 \times 10-5$ & $9 \times 10^{-5}$ & $10^{6}$ & $1.3 \times 10^{6}$ \\
\hline \multicolumn{6}{|c|}{ Case $c$ Short $t_{\frac{1}{2}}$, low concentration of all precursors } \\
\hline $238 \mathrm{pu}$ & $10^{6}$ & -- & $10-3000$ & -- & $9 \times 10^{5}$ \\
\hline $210 \mathrm{pb}$ & $10-4$ & W & Case $d$ Short $t_{\frac{1}{2}}$, high concentration of one precursor & 106 & \\
\hline $226_{R}$ & $10-3$ & & $20-3$ & 106 & \\
\hline & $10-0$ & $2 \times 10^{-3}$ & $3 \times 10^{-3}$ & $10^{\circ}$ & $1.3 \times 10^{0}$ \\
\hline
\end{tabular}

aHill and Grimwood (1978).

bThis work. 


\section{RHO-BWI-ST-9}

TABLE 8. Parameters Used in Hill and Grimwood (1979) Model.

Path Length $x=10,000 \mathrm{~m}$

Water Velocity $V=110 \mathrm{~m} \mathrm{yrs}^{-1}$

Dispersion Coefficient $=3,650 \mathrm{~m}^{2} \mathrm{yrs}^{-1}$

\begin{tabular}{|c|c|}
\hline \multicolumn{2}{|c|}{ Retardation Factors } \\
\hline Element & $\mathrm{R}$ \\
\hline $\mathrm{Se}$ & 100 \\
\hline $\mathrm{Rb}$ & 500 \\
\hline$S r$ & 100 \\
\hline $\mathrm{Zr}$ & $10^{4}$ \\
\hline Tc & 1 \\
\hline Pd & 1,100 \\
\hline Sn & 1,100 \\
\hline I & 1 \\
\hline Cs & 1,000 \\
\hline $\mathrm{Ra}$ & 500 \\
\hline Ac & 5,000 \\
\hline Th & $5 \times 10^{4}$ \\
\hline $\mathrm{Pa}$ & $1.7 \times 10^{4}$ \\
\hline U & $1.4 \times 10^{4}$ \\
\hline $\mathrm{Np}$ & 100 \\
\hline $\mathrm{Pu}$ & $10^{4}$ \\
\hline$A m$ & $10^{4}$ \\
\hline $\mathrm{Cm}$ & 3,000 \\
\hline
\end{tabular}


Long Half-Life, High Concentration of One Precursor. The initial inventory of ${ }^{234} \mathrm{U}$ considered by $\mathrm{Hill}$ and Grimwood (1978) was $73 \mathrm{Ci}$. The abundance of this nuclide increases with time due to the decay of ${ }^{238} \mathrm{Pu}$ which has an initial inventory of $1.1 \times 10^{6} \mathrm{Ci}$. The calculated transport times for the two nuclides are $1.3 \times 10^{6} \mathrm{yrs}\left({ }^{234} \mathrm{U}\right)$ and $9 \times 10^{5}$ yrs $\left({ }^{238} \mathrm{Pu}\right)$. Given a half-life for ${ }^{238} \mathrm{Pu}$ of 89 years, it may readily be seen that almost all of the ${ }^{238} \mathrm{Pu}$ decays to ${ }^{234} \mathrm{U}$ before the nuclide has travelled more than $10 \mathrm{M}\left(=\frac{10 \mathrm{t}_{2} \mathrm{~V}}{\mathrm{~V}}\right)$. Thus, ${ }^{234} \mathrm{U}$ was treated by converting all of the ${ }^{238} \mathrm{Pu}$ to ${ }^{234} \mathrm{U}$ and assuming that migration of the latter nuclide is the sole control on its $t_{c}$ and peak discharge rate. As can be seen for Table 7 , the result is in good agreement with that of $\mathrm{Hill}$ and Grimwood (1978).

The case of ${ }^{233} \mathrm{U}$ is slightly more complex, since almost all of this isotope forms from ${ }^{237} \mathrm{~Np}$, but the parent does not decay substantially during the transport period. In addition, since the parent controls the daughter abundance, it is to be expected that $t_{c}$ for ${ }^{233} \mathrm{U}$ will be controlled by $t_{c}$ for ${ }^{237} \mathrm{~Np}$. The transport time for ${ }^{233} \mathrm{U}$ was, therefore, taken to be that for neptunium $(9,000$ years) rather than that for uranium $\left(1.3 \times 10^{6}\right.$ years $)$. As can be seen from Table 7 , this approximation gives reasonable agreement with the $t_{c}$ obtained by numerical modeling. The peak concentration of ${ }^{233} U$ was obtained from the peak concentration of ${ }^{237} \mathrm{~Np}$ by calculating the amount of ${ }^{233} \mathrm{U}$ which would have formed from the ${ }^{237} \mathrm{~Np}$ during the transport time of 9,000 years. This result, $3 \times 10^{-2} \mathrm{Ci} \mathrm{yrs}^{-1}$, has to be corrected for the relative mobilities of neptunium and uranium. Thus, if neptunium and uranium moved at exactly the same velocity, the peak discharge rate of ${ }^{233} \mathrm{U}$ would be $3 \times 10^{-2}$ Ci $\mathrm{yrs}^{-1}$. Since, however, the relative velocity of uranium $\left(\frac{R_{N_{p}}}{R_{u}}\right)$ is $7 \times 10^{-3}$, the actual discharge rate is given by the product of $\frac{R}{2} \times 10^{-2}$ and $7 \times 10^{-3} \mathrm{Ci} \mathrm{yrs}^{-1}$. The exact equation embodying these assumption is:

$$
D_{U}=\frac{\lambda_{U} D_{N p}}{\lambda U-\lambda N p}\left(1-e^{-\lambda_{U} t^{t}}\right)\left(\frac{R_{N p}}{R_{U}}\right)
$$

In Equation $6, D_{U}$ and $D_{N p}$ refer to the discharge rates in $\mathrm{C} i / \mathrm{yr}$ of ${ }^{233} \mathrm{U}$ and ${ }^{237} \mathrm{~Np}$, respectively. 
Short Half-Life Low Concentrations of Precursors. The discharge rates of such isotopes can be calculated from Equation 6 in an exactly analogous manner to that already outlined for long-lived isotopes. In such cases, for example, ${ }^{238} \mathrm{Pu},{ }^{244} \mathrm{Cm}$, the calculated discharge rates are extremely small and were ignored by $\mathrm{Hill}$ and Grimwood (1978).

Short Half-Life High Concentrations of One Precursor. For nuclides with half-lives very much shorter than transport times, it is reasonable to assume secular equilibrium between long-lived parent and short-lived daughter isotopes. This requires that, in any given volume of migrating fluid, the activities of parent and daughter isotopes are identical. The transport time of the daughter is fixed by that of the long-lived parent in the same way as for case (c) above. The flow rate of parent and daughter isotopes across the boundary of the geosphere into the biosphere is, of course, given by:

$$
D=\text { Concentration } \times \text { Velocity } \times \text { Discharge Surface Area. }
$$

Thus, discharge rate of the daughter is that of the parent multiplied by the ratio of their velocities.

$$
D_{\text {daughter }}=D_{\text {parent }}\left(\frac{R_{\text {parent }}}{R_{\text {daughter }}}\right) \text {. }
$$

The relationship gives the discharge rates of ${ }^{210} \mathrm{~Pb}$ (low velocity) and ${ }^{226} \mathrm{Ra}$ (high velocity) which form from ${ }^{234} \mathrm{U}$ during transport of the latter. As can be seen, there is good agreement with the results obtained by numerical modeling.

Influence of Transport Parameters on Discharge Rate. By manipulation of the parameters in Equation 6, the following qualitative conclusions can be drawn about the peak discharge rates of important radionuclides.

(a) Sorption. Increase of the $K_{d}$ for sorption and, hence, of $R$ gives an exactly corresponding increase in time to peak $t_{c}$. For fixed leach time $T$, increase of $t_{c}$ by an order of magnitude results in approximately an order of magnitude decrease in peak discharge rate provided $t_{c}>T$. 
(b) Porosity. Porosity has the opposite effect to sorption. Increasing $\phi$ by an order of magnitude decreases $R$ and $t_{c}$ and increases the discharge rate by an order of magnitude.

(c) Dispersion. Increasing the dispersion coefficient (a) decreases the discharge rates of most nuclides. The relative effect is not as large, however, as those of sorption and porosity. If the transport time is long, an order of magnitude increase in $\alpha$ decreases the discharge rate by half an order of magnitude. If $t_{c}$ is of the same order as leach time $T$, however, there is almost no effect of $\alpha$ on discharge rate.

(d) Water velocity and path length. Increasing $x$ and decreasing $V$ are equivalent and have direct effects on $t_{c}$. Increasing $x$ by an order of magnitude increases $t_{c}$ and decreases discharge rate by half an order of magnitude.

(e) Leach rate. The effect of leach rate depends, as might be presumed from Table 6 and Equation 4 on the transport time of the isotope in question. If travel time $\left(t_{c}\right)$ is less than leach time $T$, then an order of magnitude change in leach rate will produce a corresponding order of magnitude change in discharge rate. If, however, $t_{c}$ is much greater than $T$ $\left(t_{c} / T \geq 10\right)$, then decreasing leach rate does not influence the peak concentration significantly. Thus, leach time is very important for rapidly migrating elements such as iodine, technetium, and neptunium, but of little importance for immobile elements such as uranium and curium unless the leach time is of the order of $10^{5}$ to $10^{6}$ years.

\section{Application to a Repository Located in Basalt. The calculations} discussed above were performed for the case of reprocessed high-level waste with rather arbitrary values of initial inventory, path length, and water velocity. There is no quantitative way to couple transport calculations to the hazard measure index to produce an absolute ranking of the relative hazards which the different radionuclides constitute. This is because of the wide range of release scenarios and path lengths which could be envisaged in an actual geologic repository. An 
approximate ranking of "transport hazard" was, however, obtained by performing peak discharge calculations using, whenever available, $K_{d}$ measurements made on Hanford basalt (Table 9). These calculations were performed for both spent fuel and high-level waste inventories given in Table 1. For this reference case, path length, dispersivity, and water velocity were taken to be the same as those used by Hill and Grimwood (1978) (in Table 7). Rock density was assumed to be $2.5 \mathrm{~g} \mathrm{~m}^{-3}$ and porosity 0.05 . It was assumed that leaching begins after 1,000 years and that the leach time $T$ is 3,500 years. The calculated discharge rate $(D$, $\mathrm{Ci} \mathrm{yr}^{-1}$ ) at the time of peak discharge was used to calculate a transport hazard measure (THM) per each isotope from

$$
T H M=\frac{D}{R C G} \text {. }
$$

The results for spent fuel and reprocessed waste are given in Table 10. Whenever the peak discharge time is substantially greater than 10 times the half-life of a particular isotope, the transport hazard is assumed to be zero. This is equivalent to assuming that the isotope decays completely before reaching the biosphere.

\section{CONCLUSIONS}

To identify a single list of key radionuclides using the four criteria considered above, it is necessary to combine the HM ranking of the radionuclides with the THM ranking for each radionuclide. A THM ranking was obtained by averaging the spent fuel and reprocessed waste cases given in Table 10, giving equal weight to both waste forms. The radionuclides considered in this study are ranked according to THM and HM in Table 11. In addition, an overall ranking of the key radionuclides is given, which was estimated by giving equal weight to $H M$ and transport rankings. Safety assessment studies and the design of engineered barriers should concentrate on containment of radionuclides near the top of this list. 


\section{RHO-BWI-ST-9}

TABLE 9. Sorption Distribution Coefficients (Kd) for Basalt (Ames and McGarrah, 1979).

\begin{tabular}{|c|c|c|c|}
\hline Element & Observed Range & Estimated Kd & Value Adopted \\
\hline Cs & $122-2,100$ & -- & 100 \\
\hline Sr & $58-240$ & -- & 100 \\
\hline $\mathrm{Se}$ & $0-10 *(17-80)$ & -- & 0 \\
\hline$I$ & $0-3$ & -- & 0 \\
\hline TC & $0-40 *(4,000)$ & -- & 0 \\
\hline $\mathrm{Np}$ & $3-16^{\star}(150)$ & -- & 5 \\
\hline $\mathrm{Ra}$ & $48-150$ & -- & 50 \\
\hline$U$ & $0-70 *$ & -- & 10 \\
\hline $\mathrm{Pu}$ & $10-104$ & -- & 100 \\
\hline Am & $10-105$ & -- & 100 \\
\hline Sm & -- & 100 & -- \\
\hline $\mathrm{Cm}$ & -- & 100 & -- \\
\hline $\mathrm{Pa}$ & -- & 100 & -- \\
\hline Th & -- & 100 & -- \\
\hline$A C$ & -- & 10 & -- \\
\hline $\mathrm{Zr}$ & -- & 10 & -- \\
\hline $\mathrm{Pd}$ & $-\infty$ & 10 & -- \\
\hline $\mathrm{Cd}$ & - & 10 & -- \\
\hline Sn & - & 10 & -- \\
\hline Ho & -- & 10 & -- \\
\hline $\mathrm{Pb}$ & -- & 10 & -- \\
\hline $\mathrm{Rb}$ & -- & 100 & -- \\
\hline
\end{tabular}

*Data obtained under oxidizing conditjons. Values in parentheses are for anoxic conditions ( $\mathrm{fo}_{2}=8 \times 10^{-7} \mathrm{~atm}$ ). 
RHO-BWI -ST-9

TABLE 10. Transport Hazards of Important Radionuclides.

(Leach Time $=3,500$ Years)

\begin{tabular}{|c|c|c|c|c|}
\hline Radionuc 1 ide & $\begin{array}{l}\text { Time of Peak } \\
\text { Discharge } \\
\text { Tc/yr }\end{array}$ & $\begin{array}{c}\text { Spent Fuel } \\
\text { Hazard Measure }\end{array}$ & $\begin{array}{c}\text { Reprocessed Waste } \\
\text { Hazard Measure }\end{array}$ & $\begin{array}{c}\text { Average } \\
\text { Transport } \\
\text { Hazard Measure }\end{array}$ \\
\hline${ }^{99} \mathrm{Tc}$ & 90 & $1.4 E+4$ & $1.4 E+4$ & $1.4 E+4$ \\
\hline${ }^{210} \mathrm{~Pb}$ & $4.5 E+4$ & $9.0 E+3$ & 2.6 & $4.5 E+3$ \\
\hline${ }^{226} \mathrm{Ra}$ & $4.5 E+4$ & $6.0 E+3$ & 1.7 & $3.0 E+3$ \\
\hline${ }^{129} \mathrm{I}$ & 90 & $3.0 E+3$ & 16 & $1.5 \mathrm{E}+3$ \\
\hline${ }^{79} \mathrm{Se}$ & 90 & $6.0 E+2$ & $6.0 \mathrm{E}+2$ & $6.0 \mathrm{E}+2$ \\
\hline${ }^{237} \mathrm{~Np}$ & $2.2 E+4$ & $8.0 E+2$ & 64 & $4.3 \mathrm{E}+2$ \\
\hline${ }^{126} \mathrm{Sn}$ & $4.5 E+4$ & $2.0 E+2$ & $2.0 \mathrm{E}+2$ & $2.0 \mathrm{E}+2$ \\
\hline $107 \mathrm{Pd}$ & $4.5 E+4$ & 60 & 70 & 6.5 \\
\hline${ }^{230} \mathrm{Th}$ & $4.5 E+4$ & 45 & 0.1 & 22.5 \\
\hline${ }^{233} U$ & $2.2 E+4$ & 42 & 3.0 & 22.5 \\
\hline${ }^{234} \mathrm{U}$ & $4.5 E+4$ & 30 & $9.0 \mathrm{E}-3$ & 15 \\
\hline${ }^{242} \mathrm{Pu}$ & $4.5 E+5$ & 18 & $4.0 E-2$ & 9 \\
\hline $93 m_{N b}$ & $4.5 E+4$ & 5.0 & 4.4 & 4.7 \\
\hline${ }^{238} U$ & $4.5 E+4$ & 8.6 & $2.0 \mathrm{E}-3$ & 4.3 \\
\hline${ }^{93} \mathrm{Zr}$ & $4.5 E+4$ & 2.5 & 2.2 & 2.3 \\
\hline${ }^{135} \mathrm{Cs}$ & $4.5 E+5$ & 0.3 & 0.36 & 0.33 \\
\hline${ }^{239} \mathrm{Pu}$ & $4.5 E+5$ & $5.9 \mathrm{E}-2$ & $8.6 \mathrm{E}-3$ & $3.5 \mathrm{E}-2$ \\
\hline${ }^{87} \mathrm{Rb}$ & $4.5 E+5$ & $2.0 \quad E-5$ & $4.0 \quad E-5$ & $3 E-5$ \\
\hline${ }^{90} \mathrm{Sr}$ & $4.5 E+5$ & $0--$ & $0--$ & 0 \\
\hline${ }^{151_{S m}}$ & $4.5 E+5$ & $0--$ & $0--$ & 0 \\
\hline $166 \mathrm{~m}_{\mathrm{Ho}}$ & $4.5 E+4$ & $0--$ & $0--$ & 0 \\
\hline${ }^{241} \mathrm{Am}$ & $4.5 E+5$ & $0--$ & $0 \ldots$ & 0 \\
\hline${ }^{243} \mathrm{Am}$ & $4.5 E+5$ & $0--$ & $0--$ & 0 \\
\hline $245 \mathrm{~cm}$ & $4.5 E+5$ & $0--$ & $0--$ & 0 \\
\hline
\end{tabular}


RHO-BWI-ST-9

TABLE 11. Ranking of Key Radionuclides.

\begin{tabular}{|c|c|c|c|}
\hline Radionuclide & Hazard Measure & Transport & Overall \\
\hline${ }^{99}{ }_{T C}$ & 4 & 1 & 1 \\
\hline${ }^{129} \mathrm{I}$ & 2 & 4 & 2 \\
\hline $237 \mathrm{~Np}$ & 1 & 6 & 3 \\
\hline${ }^{226} \mathrm{Ra}$ & 6 & 3 & 4 \\
\hline${ }^{107} \mathrm{Pd}$ & 3 & 8 & 5 \\
\hline${ }^{230}$ Th & 4 & 9 & $6 *$ \\
\hline $210_{\mathrm{Pb}}$ & 11 & 2 & $6 *$ \\
\hline${ }^{126} \mathrm{Sn}$ & 7 & 7 & 8 \\
\hline${ }^{79} \mathrm{Se}$ & 10 & 5 & 9 \\
\hline${ }^{242} \mathrm{Pu}$ & 8 & 12 & 10 \\
\hline${ }^{243} \mathrm{Am}$ & 9 & 19 & $11 *$ \\
\hline${ }^{234} U$ & 17 & 11 & $11 *$ \\
\hline${ }^{239} \mathrm{Pu}_{\mathrm{u}}$ & 11 & 17 & $11 *$ \\
\hline $93 m_{N b}$ & 15 & 13 & $11 *$ \\
\hline $233_{U}$ & 20 & 9 & $15 *$ \\
\hline${ }^{135} \mathrm{Cs}$ & 13 & 16 & $15 *$ \\
\hline${ }^{93} \mathrm{Zr}$ & 16 & 15 & 17 \\
\hline${ }^{241} \mathrm{Am}$ & 14 & 19 & $18 *$ \\
\hline $238 u$ & 19 & 14 & $18 *$ \\
\hline${ }^{245} \mathrm{Cm}$ & 18 & 19 & 20 \\
\hline${ }^{87} \mathrm{Rb}$ & 22 & 18 & $21 *$ \\
\hline${ }^{151} \mathrm{Sm}$ & 21 & 19 & $21 *$ \\
\hline${ }^{90} \mathrm{Sr}$ & 23 & 19 & $23 *$ \\
\hline $166 m_{\mathrm{Ho}}$ & 23 & 19 & $23 *$ \\
\hline
\end{tabular}

*Tie in ranking. 
It should be remembered that this list is subject to change as more information concerning waste forms, geology of the repository, and transport properties of the radionuclides is obtained. For example, the transport ranking depends strongly on the release scenario from the repository (flowpaths, leaching time, distance to biosphere, etc.). A very long leach time will decrease the peak discharge rate for rapidly migrating radionuclides, but will have little influence on-slow moving radionuclides.

One of the most important parameters governing the transport of radionuclides is distribution coefficient, $K_{d}$. The distribution coefficients for most of the radionuclides in Table 11 have never been measured under conditions which exist in the Columbia Plateau basalt formation. No data at all are available for sorption of ${ }^{107} \mathrm{Pd}$, ${ }^{126} \mathrm{Sn}$, and ${ }^{93} \mathrm{Zr}$ on geologic materials in the basalt. Only limited data are available for the other radionuclides in the list. Because of the lack of data, values of $k_{d}$ had to be estimated from the known chemistries of the elements and from sorption data which are not directly applicable. As more information is obtained on radionuclide sorption reactions with basalt, secondary minerals, and interbed materials, the order of apparent importance of the radionuclides in Table 11 will probably be altered.

\section{REFERENCES}

10 CFR 20, Standards for Protection Against Radiation, Title 10, Code of Federal Regulations-Energy, Part 20, Chapter 1, U.S. Nuclear Regulatory Commission, Washington, D.C.

Ames, L. L. and McGarrah, J. E., Geomedia-Radionuclide Distribution Coefficients, Fiscal Year 1979 Annual Report, PNL-3146, Pacific Northwest Laboratory, Richland, Washington, 1979.

Bell, M. J., ORIGEN - The ORNL Isotope Generation and Depletion Code, ORNL-4628, Oak Ridge NationaT Laboratory, Oak Ridge, Tennessee (1973).

Bell, M. J. and Dillon, R. S., The Long-Term Hazard of Radioactive Wastes Produced by the Enriched Uranium, Pu-238U, and 233U-Th Fuel Cycles, Oak Ridge National Laboratory, Oak Ridge, Tennessee (1971).

Bradley, D. J., Leaching of Fully Radioactive High Level Waste Glass, PNL-2664, Pacific Northwest Laboratory, Richland, Washington (1978). 
Bradley, D. J., Harvey, C. 0., Turcotte, R. P., Leaching of Actinides and Technetium From Simulated High Level Waste Glass, PNL-3152, Pacific Northwest Laboratory, Richland, Washington (1979).

Hadermann, J., "Radionuclide Transport through Heterogeneous Media," Nuclear Technology, 47, 312-323 (1980).

Hil1, M. D. and Grimwood, P. D., Preliminary Assessment of the Radiological Protection Aspects of Disposal of High Level Waste in Geologic Formations, NRPB-R69, National Radiological Protection Board, (United Kingdom) (1978).

Katayama, Y. B., Leaching of Irradiated LWR Pellets in Deionized and Typical Ground Water, BNWL-2057, Battelle Pacific Northwest Laboratories, Richland, Washington (1976).

Langmuir, D., "Uranium Solution - Mineral Equilibria at Low Temperatures with Applications to Sedimentary Ore Deposits," Geochimica et Cosmochimica Acta, 42, 547-569 (1978).

Ringwood, A. E., Kesson, S. E., Ware, N. G., Hibberson, W., and Major, A., "Immobilization of High Level Nuclear Reactor Wastes in SYNROC," Nature, 278, 219-223 (1979).

Scheetz, B. E., Komarneni, S., and Smith, D. K., "Status of the Static, Closed System, Hydrothermal Alteration Experiments of Simulated Nuclear Waste Forms," in Basalt Waste I solation Project Annual Report-Fiscal Year 1979, RHO-BWI-79-100, Rockwell Hanford Operations, Richland, Washington.

USNRC, 1980, Technical Criteria for Regulating Geologic Disposal of HighLevel Radioactive Waste, Title 10, Code of Federal ReguTations-Energy, Part 60, U.S. Nuclear Regulatory Commission, Washington, D.C.

Voss, J. W., Safety Indices and Their Application to Nuclear Waste Management Safety Assessment, PNL-2727, Pacific Northwest Laboratory, Richland, Washington (1979).

Zuber, A., "Theoretical Possibilities of the Two-Well Pulse Method," in Isotope Techniques in Groundwater Hydrology, Proceedings of 1974 Vienna Symposium IAEA, 277-294 (1974). 